\title{
A história da educação na relação com os saberes histórico e pedagógico*
}

\author{
Margarida Louro Felgueiras \\ Universidade do Porto, Faculdade de Psicologia e de Ciências da Educação
}

Na historiografia da história da educação, vários autores têm salientado a posição "entre-dois" que a disciplina ocupa (Nóvoa, 1994, p. 21; Depaepe, 1993, p. 31). Disciplina histórica, elemento estruturante da incipiente ciência da educação, só se desenvolveu historicamente no campo institucional da formação de professores, a que ficou vinculada. A partir dessa situação, sentida como desconfortável pela ambiguidade que gera ao nível da identidade dos próprios cultores, no reconhecimento académico, na afectação de recursos e nas relações de poder, discorre-se sobre as vantagens, desvantagens e potencialidades a explorar.

O objectivo deste texto é analisar a questão de forma semi-retrospectiva, partindo das recordações, quase emoções, que a experiência pessoal permite

* Este texto foi escrito em simultâneo para o relatório da disciplina "História da educação em Portugal: instituições, materiais, práticas e representações”, do mestrado em Educação e Herança Cultural, e apresentado a concurso para professora associada em ciências da educação da Faculdade de Psicologia e Ciências da Educação, Universidade do Porto (FPCE-UP), em 2005. Foi mantida a ortografia de Portugal. evocar para a partir delas caminhar na interrogação ao passado nacional e lançar um olhar sobre a situação da história da educação em outros países europeus.

\section{Do individual ao colectivo: a experiência pessoal como texto para análise}

No início dos anos de 1970, o curso de história da Faculdade de Letras do Porto era constituído por cinco anos lectivos. No final do $5^{\circ}$ ano, apresentava-se uma tese de licenciatura. Quem se destinava ao ensino, e era o inexorável destino comum, devia fazer o curso de ciências pedagógicas, frequentado então por uma verdadeira multidão de gente mais velha: professores em exercício das várias áreas do saber, professores das escolas do magistério primário. ${ }^{1}$

\footnotetext{
${ }^{1}$ Embora não sendo obrigatório para o exercício da docência, só poderia fazer carreira no ensino quem o tivesse, pois só com esse requisito poderia candidatar-se para fazer estágio pedagógico, cujas vagas eram muito limitadas. O ténue alargamento do ensino que se fez sentir no início da década de 1970 levou muitos professores com largos anos de serviço a fazer este curso, para poderem fazer estágio e passar a efectivos.
} 
Nós, estudantes ordinários da Faculdade de Letras, podíamos ir frequentando algumas disciplinas desse curso a partir do $2^{\circ}$ ano, de modo que facilitasse sua conclusão quase simultânea com a licenciatura. A história da educação e a pedagogia e didáctica figuravam no elenco das disciplinas de opção da licenciatura em história, ao lado de outras de filosofia, de arquelogia etc. Podíamos, pois, acrescentá-las ou integrá-las ao nosso plano de estudos. Sabíamos que isso nos traria vantagens no concurso para entrar em estágio e era condição indispensável para poder fazer o "exame de estado". ${ }^{2}$ Só após esse exame poder-se-ia ascender a um lugar de professor efectivo.

Discutíamos, na chamada "primavera marcelista", as lentas e ténues transformações que se estavam a dar no sistema educativo. A Reforma Veiga Simão estava em curso, com o alargamento da escolaridade obrigatória, o que implicava um aumento rápido do número de professores. Foi nesse contexto que surgiu o grau de bacharel, criado em 1968 pelo decreto n. 48.627, de 12 de outubro, obtido após três anos de frequência do plano de estudos da licenciatura (Gomes, 1995, p. 99). Com esse grau intermédio ficava-se possuidor de habilitação própria para a docência. Quem possuísse o curso de ciências pedagógicas podia concorrer de imediato ao estágio pedagógico, que começou a ser remunerado. A expansão do sistema obrigava a alargar o recrutamento e abria fissuras nas formas de controlo ideológico e político dos professores. E, ainda que o aparelho repressivo se mantivesse intacto, as formas intermédias de poder iam perdendo força.

Nós, alunas e alunos, questionávamo-nos sobre as implicações e o sentido dessas medidas: se devíamos fazer apenas o bacharelato ou completar primeiro a licenciatura, fazer o curso de ciências pedagógicas e só

${ }^{2}$ Provas públicas prestadas perante um júri, após a realização do estágio. Só depois da aprovação neste exame se poderia concorrer a um lugar do quadro, passando a professor efectivo.

${ }^{3}$ Designação dada ao período do governo de Marcelo Caetano, que inicialmente foi visto como uma esperança de abertura do regime. depois enveredar pelo ensino. A discussão girava sobre as dificuldades de entrada no estágio, com vagas muito reduzidas, o perder de oportunidades de melhor colocação se nos detivéssemos a concluir a licenciatura. A utilidade do curso de ciências pedagógicas não era discutida nem encarada como alguma coisa de muito importante do ponto de vista científico. A consciência pedagógica mais profunda resumia-se a não querer reproduzir as práticas dos nossos professores. Mas o estudo da pedagogia não era visto como significativo, tanto mais que não vislumbrávamos como alterar o sistema, a não ser alguma pequena coisa no nível da sala de aula.

Tais discussões não parecem ter influenciado grandemente o nosso percurso, pois terá sido a situação económica das famílias a determinar a entrada de muitos de nós no mundo do trabalho. Os menos resignados encontraram formas de conciliar ensino e estudo, leccionando em escolas da cidade do Porto. Foi nesse contexto que quem não tinha cadeiras em atraso se matriculou no $3^{\circ}$ ano e em algumas disciplinas pedagógicas: história da educação, higiene escolar, pedagogia e didáctica.

Que significado tinha para nós a história da educação? Era apenas mais uma disciplina de história. Começava na Antiguidade clássica e viria, talvez, no máximo, até ao Marquês de Pombal! O programa era extenso, não haveria esse risco. Ficaríamos mesmo pelo início da época moderna.

Era divertido o contacto com aquele mundo de gente mais velha! Algumas agora colegas tinham sido nossas professoras no liceu e estavam ali, remetidas ao papel de alunas, tal como nós. O contacto com elas ajudava-nos a perceber uma outra forma de olhar a realidade das escolas. Aprofundávamos a cultura clássica lendo Henry-Irénée Marrou (1971) e descobríamos termos e realidades para nós novas, como a pederastia.

Quanto à higiene escolar, leccionada por um docente da Faculdade de Medicina, tinha um número de alunos que rondava as nove centenas e uma escala de classificação muito diferente daquela a que estávamos habituadas. As notas elevadas eram frequentes. Muitos 
alunos questionavam a utilidade de saber como deveria ser a iluminação, o arejamento das salas de aula etc., pois seríamos colocados em escolas concretas, sem direito a qualquer palavra sobre as condições em que trabalharíamos. Para outros, a disciplina parecia fornecer algumas pistas no cuidado a ter na observação dos alunos e nas condições higiénicas e ergonómicas das salas de aula. De facto, para algumas mais sensíveis às questões sociais esses conhecimentos viriam a revelar sua utilidade no início da actividade profissional.

Já a pedagogia e didáctica tinha como objectivo o . estudo das doutrinas dos grandes pedagogos, uma vez que as ideias que trouxeram inovações fundamentais na pedagogia se encontram em algumas das suas obras e não nos manuais práticos de didáctica. Havia nessa formulação uma crítica a orientações comprometidas com a prática, com o real. A formação humanista pretendida era de carácter literário, de forma que garantisse um certo distanciamento que ignorasse o real e neutralizasse qualquer compromisso social. Assim, consoante o docente que a leccionava, o programa tanto podia ser a exploração e interpretação do pensamento de um autor, como Alain ${ }^{4}$ (o homem e a época, os seus meios de acção; a pedagogia de Alain: um pedagogo contra a pedagogia; fundamentos e métodos da educação, formação do carácter, o valor das humanidades, reacção aos métodos activos; conclusões), como o descrever de um conjunto de propostas pedagógicas e métodos de diferentes autores mais contemporâneos. Nesse caso partia-se de uma aproximação ao conceito de pedagogia como ciência da educação, passando por Durkheim e tendo como bibliografia Princípios de pedagogia sistemática, de Garcia Hoz, o Traité de pedagogie génèral, de René Hubert, e a Fundamentação existencial da pedagogia, de Delfim Santos. Havia ainda uma volumosa antolo-

${ }^{4}$ Alain, pseudónimo de Émile-Auguste Chartier, 1868-1951.

Filósofo, ensaísta e professor em vários liceus, entre os quais se destacam o Liceu Condorcet e o Liceu Henrique IV em Paris. Entre suas numerosas obras, traduzidas em várias línguas e sucessivamente reeditadas, conta-se Propos, pela editora Gallimard, sobre educação. gia de textos policopiados, onde tomávamos contacto com Neill e a experiência de Summerhill, Rogers, Ivan Illich, Piaget, Cousinet, Montessori, Freinet. Como alunas e alunos, pressentíamos que o desfiar dessas correntes mais não pretendia que mostrar os erros dessas utopias, "naturalmente perigosas". Talvez por isso esses autores nos apaixonavam.

Nas aulas práticas, já nos falavam da "crise da educação actual", da responsabilidade que os professores nela tinham, das suas obrigações, da participação da família na escola e da sua responsabilidade na educação dos filhos, fundamentada na doutrina social da Igreja católica, em que se esboçava, de forma muito cautelosa, uma crítica às posições oficiais. Mas tudo de forma retórica, distante, mais notória ainda quando se tratava de temas como o ensino por fichas ou os audiovisuais e a tecnologia educativa. ${ }^{5}$

Ainda mal terminara o bacharelato encontrava-me já a leccionar numa escola técnica no Porto. Tinha 20 anos. Acabaria a licenciatura a trabalhar e estudar, já depois dos anos de euforia da Revolução do 25 de abril. E essa experiência viria a influenciar decisivamente a minha carreira e a forma como passei a relacionar-me com o saber.

Recordo que o primeiro texto que escrevi e policopiei para os alunos dos cursos de electricistas, mecânicos e de construção civil foi sobre "Por que estudar história?". Questionada por eles sobre o sentido do estudo de matérias de que não viam utilidade directa, eles que eram ou provinham do sector operário, atrevi-me a elaborar um texto simples, acessível, ingénuo talvez. Mas foi uma ousadia, num tempo em que o ensino era feito exclusivamente pelo manual adoptado. Um risco, só possível dada a desagregação que se sentia do regime.

Por que estudar história? Por que ensiná-la? São interrogações que me têm acompanhado ao longo do trajecto profissional e que podem ser rastreadas no meu livro Pensar a história; repensar o seu ensino (Felgueiras, 1994). As respostas têm sido procuradas

${ }^{5}$ Para redigir este texto consultei apontamentos manuscritos de aulas, que ainda guardo, datados de 1972. 
em dois registos desde o século XIX: no próprio conhecimento histórico e nas representações sociais sobre a sua importância social. A justificação do ensino da história no currículo de uma educação básica, num tempo de grande pressão tecnológica, encontra-se pelo confronto e consenso possível sobre a formação dos cidadãos, como resultado social esperado de diferentes aprendizagens escolares e pelo seu desenvolvimento como disciplina científica. Quando, em 1988, por circunstâncias várias, reorientei a minha carreira profissional no sentido da história da educação e da introdução às ciências da educação, encontrei-me de novo face à interrogação inicial: por que ensinar história da educação? E a elaboração da resposta, dado o meu percurso e reflexão, teria de ser do mesmo tipo que a encontrada para o ensino da história. Mas há diferenças acentuadas: já não se trata de uma aprendizagem básica. O debate, centrado no currículo, continua a ser de ordem social, das expectativas que existem sobre o que deve constituir a formação de um educador, um historiador, mas trava-se, do ponto de vista científico, predominantemente no campo das ciências da educação e não no da história. Se no meu percurso pessoal e do ponto de vista epistemológico restrito a história da educação é apenas mais uma disciplina da história, inserida no campo educativo a resposta exige uma análise mais complexa.

\section{Sistematizando interrogações}

Conhecer hoje alguma coisa em profundidade implica proceder por decapagem arqueológica, procurando na sedimentação produzida pelo tempo e pela acção humana a emergência das estruturas, as dinâmicas e os sentidos que as animam. De que modo a minha própria experiência de aluna e de docente condiciona a representação que faço da realidade social, nela incluído o conhecimento científico? Ajudará ela a compreender e problematizar o lugar da história da educação no sistema de ensino?

Tomando por campo de observação Portugal, como se sedimentou a história da educação na área da formação dos docentes? Que papel aí representou? Foi essa situação insólita no panorama europeu da época ou partilha ela do mesmo tipo de necessidade, de experiência e de expectativa social? Como se fizeram sentir em Portugal os debates e realizações desenvolvidos em outros países? Como e por que se elabora o questionamento sobre o "por que ensinar história da educação? Que relação se pode estabelecer com o “por que ensinar história?". Serão essas questões pertinentes para equacionar o lugar da história da educação na actualidade? De que outras dimensões a contemporaneidade dispõe para prospectivar a história da educação e a formação dos docentes?

Decerto outras questões poderão ser levantadas, mas com esse questionário inicial pretendemos discutir o carácter híbrido da história da educação, com as dificuldades e oportunidades daí decorrentes.

\section{A história da educação em Portugal entre 1930-1970: recuo necessário}

A minha experiência de aluna do curso de ciências pedagógicas remonta ao início dos anos de 1970, num momento em que a ditadura dava já sinais de alguma convulsão interna e de incapacidade para controlar o tecido social. No campo da educação, as pressões externas e as necessidades internas decorrentes de uma guerra longa obrigavam à tomada de medidas para dar satisfação a alguns sectores que se começavam a agitar. Assim, por exemplo, as recomendações da Organização de Cooperação e Desenvolvimento Econômico (OCDE) sobre apoio social escolar, a acção da Fundação Calouste Gulbenkian e as reivindicações dos militares, que exigiam medidas de apoio para os seus filhos, originaram (Portugal, 1970) o aparecimento das primeiras e tímidas acções sobre essa matéria. As medidas mais gerais de reforma do sistema de ensino empreendidas pelo então ministro da educação nacional Veiga Simão têm de ser vistas nesse jogo de pressões para a modernização, com origens diversas.

De modo geral, a formação docente para qualquer dos níveis de ensino permanecia, nos inícios de 1970 , no mesmo registo do final dos anos de 1930. Formação pedagógica concentrada nas Faculdades de Letras de 
Lisboa, Coimbra e Porto (esta fora fechada e reiniciou o funcionamento apenas em 1962), com o curso de ciências pedagógicas, e no Instituto Nacional de Educação Física, em Lisboa. Neste, a formação pedagógica era constituída por pedagogia geral, ética, história da educação física e posteriormente história da educação, como disciplina autónoma. $\mathrm{O}$ curso de ciências pedagógicas conheceu, ao longo de 43 anos, apenas alterações de pormenor na designação de algumas das disciplinas, como anotou Gomes (1995, p. 99), sendo constituído por psicologia geral; psicologia experimental; psicologia escolar e medidas mentais; pedagogia e didáctica; história da educação, organização e administração escolar. Na realidade, esta última disciplina deixou cair a última parte da designação e assumiu-se exclusivamente como história da educação.

Em todo esse período, era reduzido o número de docentes admitidos em cada ano para frequência de um estágio de dois anos ${ }^{6}$ não remunerado no ensino secundário. A formação de professores de $1^{\circ}$ ciclo era ministrada em escolas do magistério primário, às quais se acedia tendo apenas o Curso Geral dos Liceus ${ }^{7}$ ou o Curso de Formação Feminina das Escolas Técnicas. ${ }^{8}$ O plano de estudos era de dois anos, neles incluído o estágio pedagógico, de um ano, realizado nas escolas anexas. Até 1960, a história da educação não figurava no currículo, e depois dessa data passou a integrar a disciplina de pedagogia, didáctica geral e história da educação.

${ }^{6}$ Em 1947, o decreto n. 36.507, de 17 de setembro, determinou que o estágio pedagógico do ensino secundário se fizesse apenas no Liceu D. João III, em Coimbra. Só em 1969 o estágio passou a funcionar num grande número de escolas, foi abolido o concurso de admissão, passou a ter a duração de um ano e a ser remunerado.

${ }^{7}$ O Curso Geral dos Liceus tinha a duração de cinco anos, e o seu termo correspondia a 9 anos de escolaridade.

${ }^{8}$ O Curso de Formação Feminina das Escolas Técnicas era de seis anos. O currículo, de carácter mais profissionalizante, direccionado mais para profissões na área dos serviços, dava muita ênfase a práticas de costura, bordados, desenho, culinária, puericultura, a par de escrita comercial.
Em 1971, foi introduzida uma inovação na formação dos professores liceais, com o início do ramo de formação educacional das Faculdades de Ciências, mas do qual não constava a disciplina história da educação. As disciplinas pedagógicas estavam reduzidas a psicologia pedagógica; orientação e organização escolares e metodologia; didáctica geral, que deixou de compreender a pedagogia.

Compreender a realidade da formação docente e do estado da história da educação em Portugal entre 1930 e 1974 requer não isolar o ensino e a investigação do conjunto da situação político-social do país, que condicionava a todos os níveis o quotidiano das pessoas, a sua percepção e a possibilidade de problematizar a realidade. Enquanto Nóvoa destaca, para a Europa, um período entre o primeiro conflito mundial e os anos de 1960 e outro após os mesmos até a actualidade, em Portugal a imobilidade das estruturas sociais e culturais não o permitem. Quem em Portugal pressionaria a favor da expansão da educação de base? Que novos pressupostos político-ideológicos se viam representados no aparelho de Estado ou mesmo na sociedade, de forma que exigisse mais e melhor educação? Sem o desenvolvimento do sistema educativo, que peso poderiam ter as ciências pedagógicas no panorama universitário ou nas escolas do magistério?

No quadro político, esse tempo corresponde ao terceiro período considerado por Nóvoa (1994, p. 49) na periodização que apresenta ao tratar do ensino da história da educação. Segundo Nóvoa, esse foi o período da consolidação universitária do ensino da história da educação, "contrariamente ao que se passava no estrangeiro" (1994, p. 41), pois aparece como disciplina autónoma nas universidades. Será no pós-25 de abril de 1974 que se verifica um recuo no ensino da disciplina. Apesar de Nóvoa (idem, ibidem) considerar que é possível identificar em Portugal as mesmas fases que caracterizam as tendências internacionais, é nosso entender que elas não se desenvolveram nos mesmos períodos temporais nem respondem às mesmas problemáticas socioinstitucionais.

Os docentes que leccionavam a disciplina tinham uma formação de base em filosofia e desenvolviam 
sobretudo uma docência centrada nas ideias pedagógicas. Seguindo uma tradição historiográfica herdada do século XIX, perseguem o que Marc Bloch designou pelo mito das origens. Mito que se traduzia em iniciar todos os programas nos indícios os mais afastados possíveis no tempo, geralmente na Antiguidade clássica. No caso português, esse mito tinha uma outra vertente: funcionava de justificação para não abordar as problemáticas do tempo recente. A própria ideia de recente tinha uma interpretação muito lata, que podia significar os últimos 50, 100 ou 200 anos. Daí que os temas medievais ocupassem o lugar central ou, em alternativa, as ideias educativas, olhadas do ponto de vista filosófico. Dificilmente se ultrapassaria o século XVIII. Se verificarmos a produção historiográfica nessas quatro décadas, ela é diminuta e incide sobretudo em autores do século XVIII ${ }^{9}$ ou de figuras ilustres, como a educação do rei Pedro V (Queirós, 1970). Diziam-nos que se corria o risco de perder a objectividade, de dar azo a interpretações apaixonadas que a história, ciência rigorosa, tinha de evitar. Desse modo, o positivismo aparecia como apoio a professores atemorizados pela censura, que evitavam a todo o custo poder ser acusados de permitir a livre opinião dos alunos e a contestação da realidade. Talvez por isso mesmo, quando alunos, ao exigirmos mudanças nos métodos de ensino, simultaneamente apareciam propostas de temas contemporâneos: as Conferências do Casino, no século XIX, a Primeira República, Max Weber.

Do ponto de vista dos alunos, era sobretudo por razões políticas, mais do que científicas, que não se abordavam outras temáticas. ${ }^{10}$ Era convicção de todos que estávamos atrasados décadas em relação ao que

${ }^{9}$ Afirmação reforçada por Rui Grácio em História da história da educação em Portugal: 1945-1978, reeditado nas Obras completas; e Rogério Fernandes em História da educação, história das mentalidades, história da cultura, reeditado no livro em sua homenagem, Rogério Fernandes. Questionar a sociedade, interrogar a história, (re)pensar a educação (p. 779).

${ }^{10}$ Depoimentos semelhantes encontramos em Grácio (1995), Fernandes (2004b, p. 780) e oralmente em Áurea Adão. era ensinado nos demais países europeus, que nós procurávamos conhecer através de livros franceses. Alguns eram indicados por uma nova geração de professores que procurava vencer o círculo fechado da vida intelectual em que se moviam, por meio de uma filosofia de modernização, sem questionar os fundamentos ideológicos do regime. Não se poderá entender a erupção do 25 de abril nas universidades, com as propostas radicais de novos programas, de novos currículos, sem ter em conta o sentimento de urgência profundo que animava alunos e alguns professores em quebrar os entraves ideológicos que impediam o desbravar de novas áreas e abordagens do saber. Nesse contexto, o curso de ciências pedagógicas, que não foi extinto oficialmente, apenas desapareceu nos escombros da ditadura. O seu fim representou o corte com uma erudição conotada ideologicamente e sem significado para a formação profissional. De algum modo, Joaquim Ferreira Gomes subscreve essa afirmação quando, ao descrever os males do curso de ciências pedagógicas, indicou, a par da heterogeneidade e do número excessivo de alunos, a "total falta de coordenação entre o curso e o estágio” (1977, p. 284285). E ele próprio cita Sílvio Lima, que em 1949, em seu A psicologia em Portugal, havia feito diagnóstico ainda mais contundente:

Na estrutura geral dos Cursos Pedagógicos reside um vício inato metodológico: a desintegração radical, estabelecida por lei, entre o magistério teórico universitário e o magistério prático liceal. A formação profissional do educador no Curso Pedagógico é essencialmente, se não exclusivamente, teórica, erudita, livresca, memorista. (Lima apud Gomes, 1995, p. 125)

Com a Revolução de 1974, a história da educação perdurou como disciplina optativa na licenciatura de história, nas Faculdades de Letras, enquanto eram criadas as Faculdades de Psicologia e Ciências da Educação, pelo decreto n. 12/77, de 20 de janeiro (Gomes, 1995, p. 106). Durante a ditadura encontravam-se algumas referências retóricas à necessidade de criar Faculdades de Ciências da Educação, como foi o caso 
do preâmbulo do decreto n. 18. 973, de 16 de outubro de 1930, que extingue as Escolas Normais superiores, ou o decreto n. 36.507, de 17 de setembro de 1947, que refere a necessidade de um Instituto de Ciências Pedagógicas no qual se fizesse investigação científica. Segundo o testemunho de Gomes, os reitores da Universidade de Coimbra, desde os finais da década de 1950, apoiaram ou tomaram iniciativas no sentido de propor a criação de uma licenciatura em psicologia e pedagogia, ou designação equivalente (idem, p. 99). Não foram concretizadas.

Tendo ocupado um lugar autónomo nas ciências pedagógicas, que papel representou a história da educação entre 1930 e 1974 ?

A primeira verificação é que teve poucos cultores. Muitos dos que a leccionaram eram especialistas em filosofia, em psicologia ou em outros ramos da história. Só em 1960, na Universidade de Coimbra, foi criada a Revista Portuguesa de Pedagogia, que no seu desenvolvimento tem contado com uma grande incidência de artigos de psicologia. A análise que Nóvoa apresenta dos manuais ou apontamentos de história da educação confirma que os conteúdos raramente ultrapassavam o século XVI, que o estudo de instituições, os métodos de ensino e os ideais pedagógicos eram as temáticas seleccionadas, mas só esporadicamente apareciam referências à realidade portuguesa. Nos finais da década de 1960 há uma maior incidência em pedagogos contemporâneos, mas sempre de uma forma retórica. Entretanto, no nível da história, a educação aparece integrada na história da cultura, ao falar-se da universidade, dos liceus, da filosofia, prestando-se atenção a “ensinos não-nobres” (Fernandes, 2004b, p. 783). E é pelo impulso de pessoas com sólida formação histórica, como Luís de Albuquerque, Joel Serrão e Joaquim Ferreira Gomes, e de Rómulo de Carvalho, que se inicia nas universidades alguma renovação.

Como salienta Rogério Fernandes, a partir dos anos de 1960 há, sobretudo nas disciplinas de história da cultura portuguesa e história moderna, maior sensibilidade aos temas de educação, que se traduziu na realização de trabalhos e na publicação de capítulos sobre educação em obras de carácter geral (idem, p. 781-784). Mas foi fora do quadro universitário que se produziu um conjunto de obras de referência na historiografia da educação, quer ao nível do pensamento pedagógico português, quer de análise das políticas educativas e do seu significado. Para isso não foi estranha a acção da Fundação Calouste Gulbenkian na criação de um núcleo de investigação pedagógica, dirigido por Rui Grácio, ${ }^{11}$ e no apoio à edição de obras.

Podemos afirmar que a renovação mais significativa se deu por impulso da renovação teórica que se foi produzindo no campo histórico, pela abertura a outras áreas do saber como a sociologia, as matemáticas e a antropologia, entre outras. Apesar de todas as limitações, foi o contacto com a renovação teórica que se verificava na Europa, com a Escola dos Annales, que influenciou a produção historiográfica portuguesa. Mas o interesse dos historiadores pela educação foi muito pontual, para exercer influência na historiografia da educação. E não foi a partir do campo educativo, limitado social e quantitativamente, vigiado, desvalorizado, que se produziu investigação no sentido da afirmação científica da história da educação. Integrada no curso de ciências pedagógicas, padecia como todas as outras de falta de meios humanos e materiais para evoluir, de liberdade de pensamento e de utensílios teóricos para abordar a realidade. O período de maior institucionalização do ensino da história da educação é também o da sua total dependência teórica como disciplina derivada, ante a ciência-mãe - a história, subordinação marcada por concepções do século XIX, pela ausência de questionamento e elaboração de um corpo teórico próprio.

A história da educação ficou prisioneira da estrutura dos manuais desse período, ligada à história da civilização e da cultura (Fernandes, 2004b, p. 778,

${ }^{11}$ Fizeram parte desse grupo de bolseiros da Gulbenkian, sob a direcção de Rui Grácio, Rogério Fernandes, José Salvado Sampaio, Alberto Ferreira, Fernando Castelo Branco, José Fernandes Fafe e Áurea Adão, que foi funcionária e também bolseira, e ainda Filomena Mónica, entre outros, mais na área da sociologia, que foram bolseiros no exterior. 
citando Joaquim de Carvalho ${ }^{12}$ ), ou foi encarada como "um dos elementos indispensáveis da propedêutica pedagógica" (idem, citando Alberto Pimentel Filho $^{13}$ ). Segundo Nóvoa, "tudo se resume a esforço de divulgação pedagógica" (1994, p. 85). No dizer de Rogério Fernandes, manteve um carácter descritivo, erudito, como se os factos pedagógicos tivessem sido produzidos num deserto social.

\section{Um olhar sobre as orientações da historiografia da educação europeia e seu impacto em Portugal}

O período entre as duas grandes guerras foi a todos os títulos um momento de grande efervescência cultural, que marcou o pensamento europeu do século XX. Ao nível da historiografia inicia-se o movimento dos Annales, que viria a renovar a história como disciplina social e a projectar a escola francesa em nível internacional. A história da educação, acantonada nas instituições de formação de professores, esteve desligada desse movimento inicial de renovação, constituindo, nas palavras de John Talbott, "um dos últimos refúgios da interpretação conservadora" (John Talbott, 1971, p. 146 apud Nóvoa, 1994, p. 71).

Pretendemos, neste trabalho, detectar algumas das tradições que influenciaram a historiografia portuguesa do século XX, dando atenção à construção do objecto, às teorias e aos métodos utilizados para a escrita da história da educação. Começa aqui um dos nossos problemas: até que ponto se produziu uma história da educação ou do sistema escolar, da escolarização, das ideias pedagógicas, dos métodos de ensino, dos professores? Que implicações tem na historiografia essa diferente focagem do objecto de estudo, como se procedeu, e por que, a uma passagem de um objecto para os demais?

Toda a historiografia desenvolve-se como produção de uma memória de factos socialmente notáveis e não por ilação teórica, dedutiva, da enumeração de

\footnotetext{
${ }^{12}$ História da educação (apontamentos impressos).

${ }^{13}$ Lições de pedagogia geral e de história da educação (1932).
}

aspectos da vida a preservar. É com o aumento da complexidade da vida social e do sistema económico, o desenvolvimento e a transformação de modos de vida, de hierarquias, de formas culturais e sistemas de crenças que se geram consciência de mudança e vontades de memória que originam novos objectos históricos. E esses primeiros momentos raramente são acompanhados por explicações do passado que não sirvam directamente ao estabelecimento dos factos memoráveis.

Na educação não terá sido diferente: só com o desenvolvimento dos sistemas educativos nacionais, a emergência de um corpo de professores e a necessidade da sua formação surgiu uma incipiente historiografia da educação, tal como outras disciplinas: a higiene ou a administração escolar. ${ }^{14}$ Por incipiente queremos significar uma primeira elaboração historiográfica ligada à prática educativa da formação dos alunos mestres com uma função de alargar o campo da experiência pessoal e da reflexão, com vista a adoptarem os meios e os métodos de ensino sancionados e a criar uma identidade profissional. Algo que se poderá classificar entre "a inspiração e a informação", na terminologia de Rita Saslaw e Ray Hiner (1993, p. 257), que se baseava no pressuposto do valor formativo dos conteúdos em si mesmos. Para Gabriel Compayré, a história da pedagogia era "verdadeiramente uma escola de educação, uma das fontes da pedagogia definitiva" (Compayré, 1911, p. 1.546). Historiografia amalgamada com os saberes pedagógicos, também eles em processo de autonomização ante outros saberes maiores, como a filosofia, ou em emergência, como a fisiologia, a higiene, a psicologia (Veiga \& Filho, 1999; Correia, 1988; Nóvoa, 1994, p. 19-21).

Agustín Escolano Benito (1997) exemplifica essa tendência a partir do Compendio de historia geral da educação e do ensino, de A. H. Niemeyer, que é considerado o primeiro trabalho de história da educação. Publicado em 1799, fazia parte do livro Princípios de educação e de ensino. Na linha da importante escola

${ }^{14} \mathrm{~A}$ introdução de disciplinas num determinado currículo resulta de uma negociação social complexa, que a história das disciplinas e do currículo tem vindo a explicar. 
alemã de historiografia, em que pontificaram Humbolt e Ranke e posteriormente Dilthey e que estabeleceu o que tem sido designado por historicismo ou escola metódica, apareceram as histórias da educação de Schwarz e Cramer, para quem, segundo Escolano Benito, "o conhecimento do passado era uma propedêutica fundamental para a formação dos mestres" e para “a construção de teorias educativas" (Escolano Benito, 1997, p. 53). E ainda que Herbart tenha fundado a pedagogia e a prática educativa na ética e na psicologia, aceitava que a história podia proporcionar modelos formativos. Esse modelo da historiografia pedagógica alemã constituiu uma primeira tendência, com forte repercussão na Europa e América, cruzando-se, no seu desenvolvimento, com o positivismo, servindo algumas vezes de legitimação nacionalista.

Em Portugal, Adolfo Coelho, Joaquim de Vasconcelos e Carolina Michaelis constituem no Porto, no último quartel do século XIX, um núcleo de divulgação de ideias pedagógicas muito ligado à cultura alemã, tendo dinamizado, através da Revista da Sociedade de Instrução do Porto, ${ }^{15}$ acções com vista ao desenvolvimento da educação infantil. Adolfo Coelho é por vezes considerado um precursor de uma história social da educação (Fernandes, 2004b, p. 777), mas na sua obra Noções de pedagogia elementar (1903), no capítulo reservado à evolução das ideias educativas (p. 183221), apresenta o desenrolar histórico dos sistemas pedagógicos segundo princípios gerais: sociedades de tipo produtivo ou destrutivo; em que predominam o privilégio e a opressão ou a igualdade perante a lei; o dogma ou o livre exame. Ora, esses princípios assemelham-se mais a "constantes históricas", uma espécie de leis obtidas pela análise de factos acumulados a que se procura dar sentido. Como propõe Escolano Benito, corresponde a extrapolar para a explicação

${ }^{15}$ A Sociedade de Instrução do Porto agregava vários intelectuais e figuras proeminentes do Porto, assim como alguns cidadãos de origem alemã e inglesa. Além disso mantinha correspondência e recebia donativos de livros, mapas, e até material escolar, enviados por cidadãos estrangeiros. A revista incluía ainda algumas traduções de artigos estrangeiros. histórica princípios da ciência natural, procedimento utilizado e difundido pelo historicismo alemão. O próprio Adolfo Coelho afirma que, após Froebel, último "pedagogista que trouxe à pedagogia progressiva princípios verdadeiramente novos", muitos outros vultos procuram "tirar ilações contidas nos princípios estabelecidos pelos creadores da sciencia, quer dar a esses princípios uma forma moderna ou alargal-os nas suas applicações. Entre elles, podemos citar Bell e Lencaster, o Padre Girard, Herbart, Pape Carpentier, Spencer e Bain" (Coelho, 1903, p. 210). Nota-se nesse autor um claro conhecimento das produções inglesa, alemã e francesa no campo educativo.

Na França, a influência da historiografia alemã só será suplantada pela nova história, no final da década de 1920. No campo educativo, contudo, manteve-se aquela primeira tradição na história da pedagogia, servindo a pretensa neutralidade positivista da escola metódica para legitimar versões sociologistas de progresso, identidade e coesão nacional. O Nouveau Dictionnaire de pédagogie d'instruction primaire (Buisson, 1911) dá conta dessa visão pedagogista da história da educação, subscrita por Gabriel Compayré, ao afirmar:

Dans la science de l'éducation, au contraire, comme dans toutes les sciences philosophiques, l'histoire est l'introduction nécessaire, la préparation à la science ellemême. [...] L'éclectisme, c'est-à-dire la méthode qui consiste à faire un choix dans les idées en circulation, n'aurait aucun sens dans les sciences de la nature; mais il a un rôle à jouer, et un rôle utile, dans les sciences morales, dans la pédagogie un particulier. D'ailleurs, en matière d'éducation, les erreurs elles-mêmes méritent d'être étudiées, et l'on a pu dire qu'elles constituaient autant d'expériences manquées, qui contribuent au progrès des méthodes en signalent les écueils qu'il faut éviter [...].

Elle montre nettement comment la nature humaine s'est élevé peu à peu de l'instinct à la réflexion, des conceptions étroites et mesquines à des conceptions plus larges, d'une définition incomplète de la vie et de là destinée à une ample compréhension de tous les besoins et de toutes les aspirations. (1911, p. 1.546) 
Afirmando que as doutrinas pedagógicas contribuem para formar o espírito e estabelecer os costumes, defende que uma história da educação bem compreendida é, numa forma reduzida, uma história do pensamento, podendo substituir vantajosamente no ensino popular a difícil história da filosofia e da religião. Compayré defende, assim, o lugar legítimo e indiscutível da história da pedagogia na formação dos educadores e atribui, como finalidade do ensino da história da educação, mostrar por meio de repetições, insucessos, retrocessos o progresso sempre contínuo e o encaminhamento insensível para soluções mais racionais e mais ideais.

Compayré defende que as doutrinas pedagógicas não são fruto de acontecimentos fortuitos; têm as suas causas políticas, morais, religiosas e devem ser estudadas dentro do seu contexto, evitando cair numa filosofia das ideias. Porém, o método cronológico e o programa que apresenta para o seu ensino, começando na Antiguidade clássica até ao século XIX, leva-o a propor um resumo rápido e de conjunto, assinalando os diversos períodos e suas características essenciais, o que tenderia a cair no que dizia ser de evitar.

O dicionário de Buisson, assim como algumas obras de Gabriel Compayré, foram difundidas em Portugal e exerceram influência na forma de pensar a formação docente e a história da pedagogia, por exemplo, em Alberto Pimentel Filho, Sílvio Pélico Filho e Joaquim de Carvalho, respectivamente professores nas Escolas Normais Primárias e o último, historiador da cultura portuguesa e professor do curso de ciências pedagógicas da Universidade de Coimbra (Fernandes, 2004b, p. 778-779).

Seguindo Escolano Benito (1997, p. 55-57), podemos caracterizar essa primeira tradição historiográfica por um ou mais dos seguintes elementos: prioridade à história das ideias, associada aos discursos filosóficos, descontextualizada, desenvolvendo-se segundo uma racionalidade interna e algumas vezes produzida por filósofos; ${ }^{16}$ justaposição da história das ideias com a

${ }^{16}$ É o caso, em Portugal, de Delfim Santos, que leccionou em Lisboa. das instituições; organização dos cursos ou dos manuais em função dos grandes pedagogos, sem relação com a sociedade em que viveram e a quem se atribui uma importância que na realidade não tiveram no seu tempo; instrumentalização do relato histórico com fins pragmáticos, moralizantes e políticos; organização da exposição segundo uma lógica descritiva, linear e simplista, em que se pode identificar um conjunto de ideias-força (liberdade, espírito, razão, progresso).

$\mathrm{Na}$ realidade pedagógica portuguesa, encontramos também os elementos referidos. A tendência para a instrumentalização política é mesmo a pedra de toque da emergência do que se pode considerar a primeira historiografia da educação em Portugal, no século XIX e princípios do século XX. Representantes do pensamento liberal monárquico ou republicano procuraram legitimar a acção política com recurso à evocação do passado educativo. É assim com José Silvestre Ribeiro (1871) e sua História dos estabelecimentos científicos, literários e artísticos de Portugal nos sucessivos reinados da Monarquia, em que exalta a iniciativa cultural das classes superiores; em d. António da Costa, com a História da instrução popular em Portugal, na qual exalta o liberalismo e a instrução popular, procurando explicá-la por razões de carácter social. De tendência republicana, procurando demonstrar a incapacidade da monarquia para resolver os problemas da educação, Alfredo Filipe de Matos (1907), com O passado, o presente e o futuro da escola primária portuguesa, ou Alves dos Santos (1913), com O ensino primário em Portugal, em que procura apresentar um saldo positivo da acção da República em matéria educativa. Como afirma Rogério Fernandes, estamos perante "o discurso do poder, o discurso daqueles que aparecem como sujeitos activos da história, como actores do processo da sua construção. Em suma, o discurso daqueles que têm o poder do discurso porque se situam no interior do discurso do poder" (2004a, p. 792).

Só após a $2^{\mathrm{a}}$ Guerra Mundial se rompe, na Europa, com as orientações dessa primeira tradição historiográfica. É apontada como factor determinante a afirmação científica e social da nova história. Porém, como salienta Rogério Fernandes, não pode- 
mos ignorar "a experiência histórica da educação no mundo dos nossos dias" (2004a, p. 795-796), com o prolongamento da escolaridade obrigatória, gratuita, unificada; o mérito avaliado pela escola tendendo a substituir os privilégios, a competição entre blocos, o valor estratégico atribuído à educação como questão multilateral para a qual são criadas agências internacionais para financiamento, planificação e controlo. Essas medidas instauraram um período de optimismo (décadas de 1950 e 1960), traduzido na preocupação com a democraticidade das políticas educativas, a que se seguiu nos anos de 1970, ante a crise da escola, uma análise com incidência nos níveis meso e micro do sistema educativo. Nesse período assistiu-se também a uma reflexão no interior das ciências sociais e no campo da história. Corresponde ao aparecimento da obra de Fernand Braudel e à sua direcção na revista Annales. O projecto de diálogo interdisciplinar que propôs significou uma mutação teórica e metodológica importante, indo das estruturas económicas, demográficas, às manifestações culturais.

A nova história afirma o desejo de uma história globalizante, que articule os diferentes níveis do sistema social. Faz uma síntese da aproximação à sociologia, segundo a tradição pragmática americana, e à historiografia marxista, que enfatizou a importância dos modos de produção e os condicionamentos materiais nas diferentes formações sociais. Estrutura-se à volta da revista, que difunde a nova perspectiva ao grande público francês e internacional e cria novos cultores. É também contemporânea de uma renovação historiográfica liderada pela revista Past and Present, na Inglaterra, de orientação neo-marxista, na qual pontificou Paul Thompson.

Essa nova visão do conhecimento histórico terá consequências decisivas na história da educação. A preocupação com a unidade estrutural da investigação fá-la aparecer como uma área da história, inter-relacionada com outras (demografia, economia, ciência, mentalidade, social), centrada em processos colectivos e definindo-se como uma história social da educação. Abre-se a novas temáticas, como a infância, o feminino, o currículo, as práticas na sala de aula. A tomada de consciência das diversas temporalidades determina a procura de outros registos de periodização histórica e o estabelecimento de cronologias diferenciadas.

O desafio que se colocou à história da educação foi o de se assumir como uma área da história, tal como outras abordagens, não se podendo fazer economia das suas transformações teóricas e metodológicas recentes. Há toda uma série de vinculações necessárias, com a história económica e social, com a história política, da cultura, das ciências, das técnicas, numa perspectiva interdisciplinar, para que seja possível articular as diferentes esferas da realidade e ao mesmo tempo conhecer pelo interior as práticas educativas dos estabelecimentos escolares.

Nóvoa (1994, p. 7-22) chama atenção para a heterogeneidade ideológica e metodológica desse movimento, que se estrutura nos anos de 1960 e que a terminologia americana designa como "revisionista". Sublinha a importância da sociologia no enquadramento conceptual, metodológico e no discurso crítico. Apresenta os anos de 1980 como novo ponto de viragem, caracterizado por uma grande fluidez ante a interpretação histórica, recusando que a teoria domine a priori a selecção e a interpretação. Considera existir uma recentração temática, com o regresso a questões educativas, uma diversificação metodológica e o reforço das ligações interdisciplinares. Por último, pensa que a nova história cultural e as correntes etnográficas inspiram o movimento pós-moderno, pois, atentas ao nível micro, colocam a ênfase nos processos de libertação e não tanto nos dispositivos de opressão e hegemonia (Mazurek apud Nóvoa, 1994, p. 81).

\section{A renovação historiográfica em Portugal}

Em Portugal, a renovação historiográfica começase a sentir timidamente nos finais dos anos de 1960, mas só acontece realmente nos finais dos anos de 1970. Com a alteração dos constrangimentos ideológicos, políticos e sociais que permitiu a expansão do sistema de ensino e o desenvolvimento da investigação, alargaram-se os interesses por novas temáticas, abordagens e métodos. Os professores e a profissão 
docente, a criança e a infância, os métodos de ensino, os menores em risco, a educação em internato, a cultura material da educação, a alfabetização, os liceus, o ensino técnico são algumas das temáticas que têm merecido a atenção dos historiadores desde o final dos anos de 1980. Periodicamente, nos encontros nacionais têm sido realizados e publicados balanços da produção historiográfica. ${ }^{17}$

Institucionalmente, a história da educação permanece ligada às ciências da educação, com designações, currículos e unidades de crédito muito variáveis, mas relativamente menorizada. Contudo, os historiadores da educação lograram criar uma comunidade interpretativa por meio da Secção de História da Educação da Sociedade Portuguesa de Ciências da Educação (SPCE), mantiveram um diálogo com o campo da história, estabeleceram laços com colegas de outros países através da International Standing Conference for the History of Education (ISCHE) e importante colaboração com o Brasil e com a Espanha, e impulsionaram investigações marcadas por uma concepção de história social ou com pendor sociológico. Sem abandonar a história das ideias, a institucional e a biográfica, que tem sido renovada com novas abordagens, há um crescendo de obras produzidas no campo da história social. Já em finais de 1990 e no início do século XXI apareceram trabalhos que procuram restituir o quotidiano escolar, em abordagens em que se cruzam a perspectiva etnográfica e a cultural e se presta uma progressiva atenção à cultura material escolar.

O esforço produzido procurou manter a produção nacional a par dos debates e movimentos de renovação em curso em alguns países, como os Estados Unidos da América ou a Inglaterra, que até muito recentemente não representavam um campo de influência

${ }^{17} \mathrm{Cf}$. a propósito as actas do $1^{\mathrm{o}}, 2^{\mathrm{o}}$ e $3^{\mathrm{o}}$ Encontros de História da Educação em Portugal (Lisboa, Gulbenkian, 1988), $2^{\circ}$ Encontro de História da Educação (Braga, 1998) e o recente $3^{\circ}$ Encontro de História da Educação (Porto, 2005), cujas actas estão publicadas em A história da educação em Portugal; balanço e perspectivas (Porto: ASA, 2007). com significado na historiografia em Portugal. Os desfasamentos actuais parecem ser mais quantitativas e de organização do que qualitativas, verificando-se um esforço em estar presente nos debates contemporâneos, o que os trabalhos dos próximos anos poderão vir a confirmar.

\section{O ensino da história da educação}

A análise do ensino da história da educação tende a descrever o estado da situação curricular da disciplina, as abordagens privilegiadas, o transcurso temporal abrangido, a bibliografia utilizada, os objectivos e métodos propostos. Tem merecido menos atenção a explicitação do "por que ensinar história da educação? Qual o resultado esperado do seu ensino na formação de educadores ou mesmo na formação do historiador ou do professor de história?".

Partindo do meu percurso e da reflexão que ele me proporciona, apresentarei algumas das razões que estruturam esse questionamento, que me parece prévio ao estabelecimento de objectivos, na construção curricular de um qualquer curso de história da educação. Ainda que o nível de profundidade de um programa de estudos determine alguns dos objectivos curriculares a adoptar, procurarei mostrar como também nesse tema nos encontramos no campo da história sem excluir o da educação.

Foi com alguma curiosidade que contactei com a obra de Kadriya Salimova e Erwin V. Johanningmeier, Why should we teach history of education, de 1993. De facto, o título relembrava-me a minha procura de princípios orientadores para o ensino da história no ensino básico e a necessidade de tornar clara a razão por que o julgamos defensável. Nessa época, partimos das afirmações produzidas pelos principais representantes de correntes historiográficas contemporâneas, relativas às razões de querermos conhecer o passado e à função do conhecimento histórico. Ainda que o leque de respostas fosse vasto, mostrou um fundo mais coincidente do que inicialmente parecia supor-se, manifestando-se as divergências sobretudo quanto à função social que lhe era atribuída. 
A epistemologia espontânea dos historiadores leva-os a considerar que queremos conhecer o passado para compreender a sociedade em que nos inserimos. Do ponto de vista da função social, encontrámos duas orientações distintas: uma que pensa ser o estudo da história um estimulo intelectual dos indivíduos, outra que valoriza o seu contributo para a transformação do entendimento colectivo sobre o passado e no forjar de uma outra concepção do mundo. Essa perspectiva implica um contacto com o passado de função mais socializadora, em que a história pode dar uma base de verificação para a análise dos problemas, não autorizando versões pouco fundamentadas ou preconceituosas (Felgueiras, 1994, p. 25-42). Segundo Geoffrey Partington (1980, p. 11), desde o século XIX a defesa da aprendizagem e ensino da história tem por base a promoção da compreensão histórica, pelo seu valor intrínseco para o avanço do conhecimento sobre nós próprios, individual e colectivamente, e não por razões extrínsecas ou instrumentais.

A leitura de vários dos artigos que integram o livro de Salimova, produzidos pelo Working Group for the History of Education as a Field of Research and as a Teaching Subject, no interior da ISCHE, colocanos perante a perda geral de influência da história da educação na formação de professores em nível mundial desde os anos de 1960 e apresenta alguns dos problemas teóricos e metodológicos relacionados com a estrutura e o conteúdo da história da educação como ciência. Respingaremos algumas das afirmações apresentadas para explicitar a relevância do ensino/ aprendizagem da história da educação numa Faculdade de Ciências da Educação.

Brian Simon (1993, p. 13-30) sublinha a importância de relacionar esse debate com a relação entre educação e sociedade e entre educação e mudança social. Não havendo uma resposta simples, é necessária uma análise histórica complexa para iluminar a variabilidade das mudanças educacionais. Estas apresentam momentos de alguma autonomia e poder, seguidas muitas vezes por movimentos opostos, que tendem a limitar e impedir, mesmo, o desenvolvimento de alternativas educacionais que visam o empower- ment das pessoas e das comunidades. Dentro desses movimentos sociais, de sentidos opostos e contraditórios, desde o século XIX parece existir uma certa ligação entre teoria e prática, expressa na teoria clássica do desenvolvimento humano e suas implicações no ensino.

O trabalho de Alexandre Bain, Education as a science, de 1879, é apresentado como o culminar desse posicionamento, combatido no início do século $\mathrm{XX}$ pelas teorias psicométricas, fundadas na hereditariedade, que procuraram legitimar a estagnação social e educativa com base na incapacidade e nas diferenças entre indivíduos. Segundo Simon, a análise histórica permite mostrar a importância das ideias no tipo de desenvolvimento que se escolhe e apresenta a educação como um campo de luta das forças sociais, onde emerge a mudança social, pelo estabelecimento de políticas e pelo compromisso entre pensamento e acção. A sua análise, baseada na história da educação no Reino Unido, é influenciada pela obra de Fred Clarke, que conclui ser importante a história da educação na formação de professores para interpretarem as actividades e concepções do passado à luz do conflito de interesses e sua expressão social e política. Nesse sentido, a perspectiva histórica "opens the theachers' eyes to the real nature of their work" (Clarke apud Simon, 1993, p. 28), promovendo a consciência crítica dos professores, antídoto contra as práticas rotineiras e a perda de sentido, impeditivas de inovação e avanço social.

Marc Depaepe, tal como António Nóvoa, sublinha que as respostas que têm sido dadas em nível internacional sobre o valor do estudo da história da educação indicam seu carácter híbrido e a dificuldade de aceitação, quer no campo histórico quer entre as ciências da educação. Marc Depaepe questiona se o valor prático, tantas vezes invocado, não violentará a história e não correrá o risco de anacronismo, de distorção dos dados ao pretender sustentar uma teoria educacional. A justificação do ensino da história a partir de factores extrínsecos, como a promoção do pensamento crítico, a relativização dos problemas com base num olhar mais abrangente, o interesse pela profissão etc., 
pode levar à mistificação. Em reacção a esse tipo de abordagem utilitária, Depaepe (1993, p. 33-34) indica a defesa, nos Estados Unidos, de uma abordagem puramente intrínseca, de procurar satisfazer apenas o desejo de conhecer, que, na melhor das hipóteses, pode situar o pensamento e as práticas educacionais em uma estrutura de tempo mais alargada.

Essa perspectiva liberal de neutralidade tem sido criticada pelos historiadores sociocríticos, pois isso não previne o viés e pode contribuir para a irrelevância do saber. Depaepe acaba por defender que, quaisquer que sejam a abordagem, o recorte temporal ou espacial da investigação, esta tem de seguir as regras da pesquisa histórica. As questões podem ser estudadas a partir de uma problematização elaborada no campo da educação, mas os fenómenos pedagógicos devem ser analisados historicamente. Esses dois pólos - história e educação - podem ser vistos como complementares de um continuo entre os quais se deslocam questionamentos e contributos reconhecidos pelo seu valor heurístico que ajudam a relativizar também o valor de cada nova abordagem.

Todas as perspectivas expostas não se afastam do que já encontráramos afirmado por outros historiadores para o ensino da história: o contributo do ensino da história da educação para o desenvolvimento individual e colectivo, a valorização feita por meio de factores de ordem extrínseca ou intrínseca. Há ainda uma dimensão afectiva que tende a ser valorizada, principalmente se se considera o gosto pelo conhecimento, e factores de ordem extrínseca, que se prendem com noções de relevância curricular, com concepções sobre a formação dos alunos. Sobretudo, está presente um valor intrínseco do conhecimento histórico como disciplina capaz de interrogar e analisar dados do passado, situando-os em estruturas de compreensão mais amplas. Essa identidade de perspectivas reflecte uma certa unidade entre diferentes objectos de estudo e abordagens da história. Considera Rogério Fernandes que, na actualidade, a história da educação "gera ela própria um contexto social, é ela própria uma cultura" (2004a, p. 803), na medida em que o trabalho dos historiadores cria uma visão da realidade que contri- bui directamente para instituir o olhar que sobre ela temos, o que confere uma unidade multifacetada ao discurso histórico.

No âmbito da formação, Rogério Fernandes questiona se "será pertinente definir a história da educação não apenas como disciplina de formação profissional de professores mas também como área do próprio saber histórico". E interroga se é hoje possível pensar a explicação da sociedade sem se ter em conta a forma como educa os mais jovens. E, sendo negativa essa hipótese, considera que

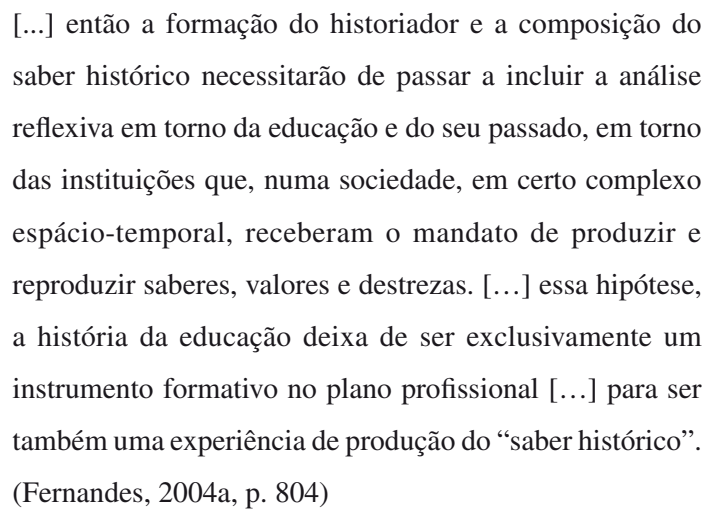

Nessa perspectiva intradisciplinar, que igualmente subscrevo, verifica-se um aumento progressivo da visibilidade dos temas de educação na formação pósgraduada, um pouco por todos os países. O que nos permite concluir, tal como Rogério Fernandes, que a história da educação participa do saber como do fazer histórico. Relativamente à sua relevância esta se situa na posição teórica que é assumida, pois marca diferenças significativas na definição do objecto, na escolha da abordagem e do local donde se fala. No campo histórico, há mesmo quem afirme existir um distanciamento maior entre posicionamentos teóricos do que entre áreas da história (Rabb \& Rotberg, 1982; Felgueiras, 1994, p. 26). Considerando a localização institucional dos investigadores, verifica-se que a relação que se pode estabelecer com a construção teórica é diferencial. Essa articulação é também estruturante de novas pesquisas e interpretações, num campo científico em que o diálogo interdisciplinar tende a desempenhar um papel mais activo na construção do objecto de investi- 
gação. E isso sem diminuir a sua pertença às ciências da educação, o papel propedêutico que desempenhou no constituir dessa área e desempenha na formação de educadores. A história da educação estará atenta para restituir e reconhecer as constâncias e as emergências de problemas educacionais que tanto nos preocupam, assim como as expectativas sociais que geram.

\section{O ensino da história da educação em Portugal na actualidade}

O primeiro balanço sobre o ensino e a investigação da história da educação em Portugal foi realizado sob os auspícios da Fundação Calouste Gulbenkian em 1988, por iniciativa de Rogério Fernandes e Áurea Adão. ${ }^{18}$ Em 1993, António Nóvoa promoveu um balanço da investigação nesse campo ao organizar o $1^{\circ}$ Encontro Ibérico de História da Educação, cujos textos foram igualmente publicados (Nóvoa \& Berrio Ruiz, 1993); em 1994, nas suas provas de agregação, apresentou um estudo sobre o ensino, a investigação e as perspectivas em história da educação (Nóvoa, 1994). ${ }^{19}$ Justino de Magalhães (1998), ao realizar o $2^{\circ}$ Encontro Nacional de História da Educação, promoveu um segundo balanço sobre o ensino da disciplina, que nove anos volvidos se tornou a realizar, por ocasião do $3^{\circ}$ Encontro Nacional, efectuado no Porto em 2005.

Esses sucessivos balanços do ensino e da investigação traduzem a necessidade de um contínuo situar da disciplina nesses dois contextos a par das preocupações em relação ao seu futuro, num tempo em que a pressão tecnológica leva a desvalorizar conteúdos "menos úteis". O esforço de análise sobre a pesquisa efectuada detectou a emergência de novas temáticas e abordagens e, em relação ao ensino, permitiu apreciar a evolução dos currículos, as tendências da sua

\footnotetext{
${ }^{18}$ Atas do $1^{\circ}$ Encontro de História da Educação em Portugal. “Comunicações”. Lisboa: Fundação Calouste Gulbenkian/Serviço de Educação, 1988.

${ }^{19}$ Agradeço ao autor a amabilidade da oferta de um volume ainda mimeografado, que me tem sido muito útil, como o uso que dele faço neste trabalho, e não só, o confirma.
}

afirmação ou regressão nas instituições, apesar de no momento não serem perceptíveis as alterações que o processo de Bolonha e a instabilidade que se vive nas instituições de ensino superior possam trazer nesse domínio. $^{20}$

Os primeiros balanços produzidos situam-nos em relação a um passado mais afastado, pelo que nos localizaremos aqui na análise mais recente. Com essa finalidade, apresentaremos uma síntese do trabalho realizado por Maria Teresa Santos, ao $3^{\circ}$ Encontro de História da Educação, ${ }^{21}$ uma vez que são os dados recolhidos mais recentemente.

Teresa Santos constata que, apesar da autonomia disciplinar e epistemológica da história da educação, esta assume actualmente uma variedade de designações: história da pedagogia e da educação, história das ideias contemporâneas em educação, correntes contemporâneas das ideias educativas e história e políticas educativas contemporâneas, entre outras. Essa multiplicidade de denominações não é consensual e surge como arbitrária e pouco fundamentada. Já a presença curricular é visível nos planos curriculares das licenciaturas direccionadas para a formação de professores de $1^{\circ}, 2^{\circ}$ e $3^{\circ}$ ciclos, educação de infância e ciências da educação. É leccionada nos primeiros anos das licenciaturas em doze universidades públicas e três privadas. Regista-se ainda a presença em cursos de pós-graduação, quer na sua área específica quer em programas interdisciplinares. Porém, a disciplina aparece muitas vezes associada a outra, possivelmente como "estratégia para encontrar um espaço no plano curricular que ofereça resistência ou favoreça o

${ }^{20}$ Processo de Bolonha designa a adaptação dos currículos nacionais de ensino superior, de acordo com uma directiva da Comunidade Europeia, a fim de uniformizar a obtenção de graus académicos no espaço europeu e permitir a equivalência das formações e a circulação dos diplomados.

${ }^{21}$ Utilizaremos o trabalho de Maria Teresa Santos, amavelmente cedido pela autora, por incidir sobre o ensino da disciplina em universidades. Para esse estudo a autora recolheu informação em sites das universidades e administrou um inquérito aos docentes que leccionaram as disciplinas entre 2003 a 2005. 
adiamento da extinção de uma das disciplinas ou de ambas" (Santos, 2007, p. 7). A autora sublinha como aspectos positivos a abertura e a procura de afinidades com disciplinas da mesma área, de que a junção história e filosofia da educação são um exemplo - não isento de problemas, uma vez "que os procedimentos hermenêuticos e o horizonte de sentido das disciplinas são diferentes" (Santos, 2007, p. 8) -, e conclui que "a geminação é preocupante se induzir à menoridade da disciplina, se a desvitalizar epistemologicamente e se a empobrecer por perda de territorialidade curricular" (idem, ibidem). O inquérito revelou a presença da história da educação em programas transversais, o que expressa a importância da temporalidade no interrogar da acção educativa, mas tende a tornar a disciplina invisível, para o que Rogério Fernandes já chamara a atenção.

Os programas de história da educação caracterizam-se pela grande diversidade de conteúdos, fruto da formação pessoal dos seus autores e, nalguns casos, de um esforço de adaptação à particularidade das licenciaturas em que se inserem. Segundo Maria Teresa Santos, a matriz histórica oscila entre uma aliança filosófica, sociológica ou psicológica, o que determina abordagens heterogéneas, orientações divergentes e discursos científicos diferenciados, que raramente deixam transparecer o modelo de racionalidade científica eleito (idem, p. 9). De qualquer modo, parecem estar longe

\section{[...] das concepções de objectividade histórica do positivis- mo, quer da concepção hegeliana marcada pelas ideias de desenvolvimento (Entwicklung) e de superação (Aufhebung) de uns modelos educativos por outros e pela teleologia imanente ao pensamento pedagógico em vista, quer da perfectibilidade quer do sentido único da vida humana. (idem, p. 10)}

A reflexão sobre conceitos, pressupostos e métodos é geralmente esquecida, assim como os programas raramente reservam um momento introdutório dedicado à explicitação do estatuto epistemológico e enquadramento da própria disciplina.
Relativamente à organização dos conteúdos, a autora que vimos seguindo distinguiu três modalidades: a vertical, a espácio-temporal e a horizontal. Em relação à primeira, que sistematiza as matérias a apresentar e desenvolver de forma cronológica, verifica-se uma tendência para a extensividade e outra compreensiva, que selecciona épocas ou temas. A organização espácio-temporal parece ser a escolha principal, dando, contudo, lugar a uma enorme variedade de programas em que se entrecruzam a cronologia e as temáticas, num vaivém entre o global e o local, em que a especificidade da educação em Portugal tem lugar assegurado. Esse tipo de estrutura programática é o que permite maior adaptabilidade às exigências institucionais, à permeabilidade entre investigação e docência, à própria interdisciplinaridade no seio das ciências da educação, mantendo ao mesmo tempo a especificidade do trabalho histórico. A modalidade horizontal recorre a textos ou autores paradigmáticos, que são geralmente extensos e acusam um pendor descritivo em que se alinham de modo avulso autores, instituições, métodos ou políticas.

Maria Teresa Santos conclui que, no seu conjunto, os programas actuais se revelam ora propedêuticos e generalistas ora mais concentrados e selectivos. São abertos, plásticos, com opções assumidas e particularidades que os individualizam (idem, p. 11). Fruto da autonomia e de um certo isolamento académicoinstitucional, a análise dos conteúdos agrupados pelos diferentes recortes sugeridos permite combinações tão diversas que criam uma imagem de mancha de contornos variáveis (efeito patchwork), o que pode também ser interpretado como ausência de debate ou de espaço de intervenção sobre a actividade de docentes e investigadores de história da educação. Entende que os docentes estariam perante dois tipos de pressão: uma integradora, que procura olhar a educação dentro do contexto histórico; outra que visa garantir a consistência de abordagens ou de temáticas seleccionadas, omitindo tudo o mais. Regista ainda um deficit de reflexão epistemológica, demonstrada pela ausência de referências introdutórias sobre o estatuto e a historicidade da disciplina e de internalização das 
questões de género. Afirma ainda que o "tradicionalismo académico assume-se como constante", com o recurso preferencial à metodologia expositiva, da responsabilidade do docente. "A metodologia das aulas práticas incorpora a hermenêutica como base de trabalho participada por docentes e discentes e, quase por excepção, remete para a pesquisa documental ou oferece a possibilidade de pesquisa de campo" (idem, p. 13). Essa constatação remete para outra: a da falta de comprometimento interventivo que os programas revelam e que contribui também para a invisibilidade da disciplina. Aponta como eixos de reflexão a falta de cooperação e parceria entre investigadores e a necessidade de investimento na transversalidade da disciplina, com a possibilidade de entrar de direito e com interrogações próprias em áreas vizinhas e na visibilidade desse processo.

A descrição feita sobre a situação da história da educação nos cursos universitários em Portugal parte de um ponto de vista curricular e educacional, mais do que epistemológico. Manifesta algumas das preocupações dos docentes quanto à relevância da formação que promovem, à sua própria visibilidade académica, às possibilidades de intervir e de investigar. E, ainda que não possamos isolar completamente o debate epistemológico das circunstâncias reais em que se pratica a pesquisa e a docência, convém destrinçar a ordem teórica das condições empíricas. Desse modo, concebendo a educação como uma intervenção pensada historicamente num espaço social, torna-se imprescindível uma reflexão sobre o que ensinar e para quê - o que nos remete para a importância do que ensinamos e propomos como aprendizagens aos alunos. Daí que a preocupação com a articulação curricular, a perda de referenciais epistemológicos que a legitimem e individualizem, o uniformizar da designação, a necessidade de reflectir sobre as metodologias de ensino de forma que tornem visíveis os procedimentos julgados importantes tenham guiado o estudo que sumariámos e sejam amplamente partilhados pelos docentes universitários da história da educação. As fragilidades que a análise dos programas revela correm o risco de contribuir para a invisibilidade académica da disciplina e dos seus cultores, assim como para o empobrecimento cultural do campo educativo.

Contudo, pensamos que é necessário centrar o debate no campo teórico da história da educação, da possibilidade científica de articulação de novas abordagens e novos objectos com a necessidade de constituição de uma sólida cultura histórica e de competências de investigação em história da educação. A explicitação de pressupostos, o rigor dos procedimentos de pesquisa, a preservação da identidade da história da educação devem acompanhar uma atitude de abertura à cooperação e ao trabalho interdisciplinar. Mas torna-se indispensável voltar ao debate de questões epistemológicas básicas, como sobre: facto e interpretação; sujeito actor e narrador; sujeitos e estruturas; autenticidade, significado e veracidade; estatuto do testemunho oral e material; difusão de modelos e interligação de culturas.

Ou seja, parece indispensável retomar o debate no seio da história e, em simultâneo, questionar a educação sobre evidências consensualizadas e perspectivar na temporalidade os novos problemas. A reflexão sobre essas e outras questões pertinentes do ponto de vista teórico-metododológico repercutir-se-á no articular dos conteúdos programáticos e nas metodologias de ensino a ensaiar.

\section{Referências bibliográficas}

BUISSON, Ferdinand. Nouveau dictionnaire de pédagogie d'instruction primaire. Paris: Hachette, 1911.

COELHO, Adolfo. Noções de pedagogia elementar. Lisboa: Empreza da História de Portugal, 1903.

COMPAYRÉ, Gabriel. Histoire de la pédagogie. In: BUISSON, Ferdinand. Nouveau dictionnaire de pédagogie d'instruction primaire. Paris: Hachette, 1911. Disponível em: <http://www.inrp. fr/edition-electronique/lodel/dictionnaire-ferdinand-buisson/document.php?id=3354\&format=print $>$. Acesso em: 10 maio 2007. CORREIA, José Alberto. Para uma teoria crítica em educação. Porto: Porto, 1988.

DEMARTINI, Zeila B. F. Culturas escolares: algumas questões para a história da educação. In: FERREIRA, António Gomes. (Org.). Escolas, culturas e identidades. Coimbra: Comunicações, 
v. I, III Congresso Luso-Brasileiro de História da Educação/SPCE, 2004. p. 91-101.

DEPAEPE, Marc. Some statements about the nature of the history of education. In: SALIMOVA, Kadriya; JOHANNINGMEIER, Erwin. Why should we teach history of education? Moscovo: The Library of International Academy of Self-Improvement, 1993. p. 31-36.

ESCOLANO BENITO, Agustín. La investigación en historia de la educación en España: tradiciones y nuevas tendencias. In: NÓVOA, António; RUIZ BERRIO, Júlio (Eds.). A história da educação em Espanha e Portugal. Investigações e actividades. Lisboa: Sociedade Portuguesa de Ciências da Educação e Sociedade Española de Historia de la Educación, 1993. p. 65-83.

. La historiografia educativa. Tendências generales.

In: GABRIEL, Narciso; VIÑAO FRAGO, António (Eds.). La investigación histórico-educativa. Tendências actuales. Barcelona: Ronsel, 1997. p. 51-84.

. La historia de la educación después de la posmodernidad. In: RUIZ BERRIO, Júlio (Ed.). La cultura escolar de Europa. Tendências históricas emergentes. Madrid: Biblioteca Nueva, 2000. p. 297-323.

Las culturas escolares en España en la perspectiva histórica. In: FERREIRA, A. Gomes (Org.). Escolas, culturas e identidades. Coimbra: Sociedade Portuguesa de Ciências da Educação, III Congresso Luso-Brasileiro de História da Educação, v. I, 2004. p. 113-127.

FELGUEIRAS, Margarida Louro. Apontamentos manuscritos de aulas de história da educação e de pedagogia e didáctica, na FLUP, 1972.

. Pensar a história, repensar o seu ensino. Porto: Porto, 1994.

; MENEZES, Maria Cristina. Rogério Fernandes.

Questionar a sociedade, interrogar a história, (re)pensar a educação. Porto: Afrontamento/FPCEUP, 2004.

FERNANDES, Rogério. As ideias pedagógicas de F. Adolfo Coelho. Lisboa: Instituto Gulbenkian de Ciência/Centro de Investigações Pedagógicas, 1973.

História da educação e o saber histórico. In: FEL-

GUEIRAS, Margarida Louro; MENEZES, Maria Cristina. Rogério

Fernandes. Questionar a sociedade, interrogar a história, (re)pensar a educação. Porto: Afrontamento/FPCEUP, 2004a. p. 789-805.

. História da educação, história das mentalidades, história da cultura. In: FELGUEIRAS, Margarida Louro; MENE-
ZES, Maria Cristina. Rogério Fernandes. Questionar a sociedade, interrogar a história, (re)pensar a educação. Porto: Afrontamento/ FPCEUP, 2004b. p. 773-787.

FARGE, Arlete. Lugares para a história. Porto: Teorema, 1999. [1. ed. Seuil, 1997.]

GABRIEL, Narciso; VIÑAO FRAGO, Antonio (Eds.). La investigación histórico-educativa. Tendências actuales. Barcelona: Ronsel, 1997.

GOMES, Joaquim Ferreira. Dez estudos pedagógicos. Coimbra: Almedina, 1977.

Para a história da educação em Portugal. Porto: Porto, 1995.

. A investigação em história da educação em Portugal. In: NÓVOA, António; RUIZ BERRIO, Júlio (Ed.). A história da educação em Espanha e Portugal. Investigações e actividades. Lisboa: Sociedade Portuguesa de Ciências da Educação e Sociedade Española de Historia de la Educación, 1993. p. 55-64.

GRÁCIO, Rui. História da história da educação em Portugal: 19451978. In: FUNDAÇÃO CALOUSTE GULBENKIAN (Ed.). Obras completas. V. I Lisboa: Gulbenkian, 1995. p. 495-535.

HELLER, Agnés. O cotidiano e a história. 4. ed. São Paulo: Paz e Terra, 1970.

HOZ, Vitor G. Princípios de pedagogia sistemática. Porto: Civilização, 1970.

HUBERT, René. Traité de pedagogie génèral. Paris: Presses Universitaires Françaises, 1961.

JOHANNINGMEIER, Erwin. V. The history of education as a teaching subject: its nature, purposes, and methods. In: SALIMOVA, Kadriya; JOHANNINGMEIER, Erwin. Why should we teach history of education? Moscovo: The Library of International Academy of Self-Improvement, 1993. p. 52-65.

MAGALHÃES, Justino (Ed.). Fazer e ensinar história da educação. In: ENCONTRO DE HISTÓRIA DA EDUCAÇÃO, 2., Braga, 1998. Actas... Braga: Instituto de Educação e Psicologia/Centro de Estudos em Educação e Psicologia da Universidade do Minho, Secção de História da Educação SPCE, 1998.

MARROU, Henri-Irenée. História da educação na Antigüidade. São Paulo: Herder, 1971.

NÓVOA, António. Perspectivas de renovação da história da educação em Portugal. In: NÓVOA, António; RUIZ BERRIO, Júlio. (Eds.). A história da educação em Espanha e Portugal. Investigações e actividades. Lisboa: Sociedade Portuguesa de Ciências da Educação e Sociedade Española de Historia de la Educación, 1993. p. 11-22. 
História da educação. Lisboa: Faculdade de Psico-

logia e Ciências da Educação, 1994. [Relatório apresentado para provas de agregação.]

; BERRIO RUIZ, Júlio (Eds.). A história da educação em Espanha e Portugal; investigações e actividades. Lisboa: Sociedade Portuguesa de Ciências da Educação e Sociedade Española de Historia de la Educación, 1993.

PARTINGTON, Geoffrey. The idea of an historical education. Windsor: NFER Publishing, 1980.

PORTUGAL. Decreto-lei n. 358/70, de 29 de julho de 1970. Diário do Governo, n. 175, 1970.

QUEIRÓS, Francisco A. Fortunato. D. Pedro V e a educação: ideário pedagógico de um rei. Porto: Edição do autor, 1970. [Dissertação de licenciatura em ciências históricas apresentada à Faculdade de Letras da Universidade do Porto.]

RABB, Theodore K.; ROTBERG, Robert I. (Eds.). The new history. The 1980 and the beyond. Princeton: Princeton University Press, 1982.

Revista da Sociedade de Instrucção do Porto, 1881-1883.

RIOUX, Jean-Pierre; SIRINELLI, Jean-François. Para uma história cultural. Lisboa: Estampa, 1998.

SALIMOVA, Kadriya; JOHANNINGMEIER, Erwin. Why should we teach history of education? Moscovo: The Library of International Academy of Self-Improvement, 1993.

SANTOS, Delfim. Fundamentação existencial da pedagogia. 2. ed. Lisboa: Livros Horizonte, 1971.

SANTOS, Maria Teresa. Perfil da história da educação: conflito entre o empobrecimento efectivo e o potencial objectivo. In: PINTASSILGO, Joaquim; ALVES, Luís Alberto; CORREIA, Luís Grosso; FELGUEIRAS, Margarida Louro (Orgs.). A história da educação em Portugal: balanço e perspectivas. Porto: Asa, 2007. [Apresentado no Porto, $3^{\circ}$ Encontro de História da Educação, 1-2 de abril de 2005.]

SASLAW, Rita S.; HINER, N. Ray. What are we teaching in the history of education? In: SALIMOVA, Kadriya; JOHANNINGMEIER, Erwin (Eds.). Why should we teach history of education? Moscovo: Library of International Academy of self-improvement, 1993. p. 245-263.

SIMON, Brian. The history of education: its importance for understanding. In: SALIMOVA, Kadriya; JOHANNINGMEIER,
Erwin (Eds.). Why should we teach history of education? Moscovo: Library of International Academy of self-improvement, 1993. p. 13-30.

SOLÀ, Pere. The history of education between two explosions: the explosion of the disciplinary unity of history and that of traditional humanism. In: SALIMOVA, Kadriya; JOHANNINGMEIER, Erwin (Eds.). Why should we teach history of education? Moscovo: Library of International Academy of Self-Improvement, 1993. p. 66-79.

VEIGA, Cynthia Greive. História política e história da educação. In: .; FONSECA, Thais Nivia de Lima (Orgs.). História e historiografia da educação no Brasil. Belo Horizonte: Autêntica, 2003. ;; FILHO, Luciano Mendes Faria. A infância no sótão.

Belo Horizonte: Autêntica, 1999.

VIÑAO FRAGO, Antonio. De la importancia y utilidad de la historia de la educación (o la responsabilidad moral del historiador). In: GABRIEL, Narciso; VIÑAO FRAGO, Antonio (Eds.). La investigación histórico-educativa. Tendências actuales. Barcelona: Ronsel, 1997.

MARGARIDA LOURO FELGUEIRAS, doutora pela Universidade do Porto, é investigadora do Centro de Investigação e Intervenção Educativas da mesma universidade, atuando na Faculdade de Psicologia e Ciências da Educação. Publicações recentes: Para uma história social do professorado primário em Portugal no século XX. Uma nova família: o Instituto do Professorado Primário Oficial Português (Porto: Campo das Letras, 2008); “A organização do tempo da criança em internato" (In: FERNANDES, Rogério; MIGNOT, Ana Chrystina Venâncio. O tempo na escola. Porto: Profedições, 2008); "A literatura como representação de possibilidades" (In: GOMEZ GARCIA, Maria N.; FLECHA GARCIA, Consuelo; CORTS GINER, M. Isabel (Eds.). La literatura y la educación: perspectivas históricas. Educación en la literatura y literatura en la educación. Sevilla: Cajasol, 2007); "Cenografias da escolarização. Os edifícios escolares da ditadura. Contributos" (Revista Estudos do Século XX, n. 6, 2007). E-mail: margafel@fpce.up.pt

Recebido em dezembro de 2007 Aprovado em junho de 2008 
Margarida Louro Felgueiras

\section{A história da educação na relação com os saberes histórico e pedagógico}

Na historiografia da história da educação, vários autores têm salientado a posição "entre-dois" que a disciplina ocupa (Nóvoa, 1994, p. 21; Depaepe, 1993, p. 31). Disciplina histórica, elemento estruturante da incipiente ciência da educação, só se desenvolveu historicamente no campo institucional da formação de professores, a que ficou vinculada. A partir dessa situação, propomo-nos analisar a questão de forma semi-retrospectiva, evocando recordações da experiência pessoal. A partir delas, caminhamos na interrogação ao passado, tomando Portugal por campo de observação, ao mesmo tempo em que lançamos um olhar sobre a situação da história da educação em outros países europeus. Pretendemos problematizar o lugar da história da educação no sistema de ensino, compreender como se sedimentou a história da educação na área da formação dos docentes e que papel aí representou. Da sistematização de algumas questões em torno dessa problemática pretendemos discutir o carácter híbrido da história da educação, com as dificuldades e oportunidades daí decorrentes.

Palavras-chave: história da educação; saber pedagógico; formação de professores; ensino da história da educação

\section{The history of education in relation to historical and pedagogical knowledge}

In the historiography of the history of education, different authors have emphasized the "in-between" position which the discipline occupies (Nóvoa, 1994, p. 21; Depaepe, 1993, p. 31). The discipline, a structuring element in the incipient science of education, developed historically only in the institutional field of the training of teachers, to which it became linked. Based on this situation, we propose to analyze the question in a semiretrospective manner, evoking memories of personal experience. Based on these, we shall interrogate the past, taking Portugal as our field of observation whilst at the same time taking a look at the situation of the history of education in other European countries. We intend to problematize the place of the history of education in the field of teacher training and the role which it represents there. Starting with a systematization of some questions related to this theme, we intend to discuss the hybrid nature of the history of education, with the difficulties and opportunities inherent in it.

Key words: history of education; pedagogical knowledge; teacher training; teaching of the history of education

La historia de la educación en la relación con los saberes histórico y pedagógico

En la historiografía de la historia de la educación, varios autores han resaltado la posición "entre dos" que la diciplina ocupa (Nóvoa, 1994, p. 21; Depaepe, 1993, p. 31). Diciplina histórica, elemento estructural de la incipiente ciencia de la educación, sólo se desarrolla históricamente en el campo institucional de la formación de profesores, a la que quedó vinculada. A partir de esa situación nos proponemos analizar la cuestión de forma semi retrospectiva, evocando recordaciones de la experiencia personal. A partir de ellas, caminamos en la interrogación al pasado, tomando Portugal por campo de observación, al mismo tiempo que lanzamos una ojeada sobre la situación de la historia de la educación en otros países europeos. Pretendemos problematizar el lugar de la historia de la educación en el sistema de enseñanza, comprender como se sedimentó la historia de la educación en el área de la formación de los docentes y que papel ahí representó. De la sistematización de algunas cuestiones en vuelta de esa problemática, pretendemos discutir el carácter híbrido de la historia de la educación, con las dificultades y oportunidades de ahí transcurridas.

Palabras clave: historia de la educación; saber pedagógico, formación de profesores; enseñanza de la historia de la educación

Cynthia Greive Veiga

Escola pública para os negros e os pobres no Brasil: uma invenção imperial

$\mathrm{O}$ artigo apresenta dados finais de pesquisa sobre a escolarização de crianças pobres, negras e mestiças no Brasil, especificamente na província de Minas Gerais, durante a vigência da Monarquia constitucional (1824-1889). Para seu desenvolvimento, foram investigados diferentes documentos da instrução pública; a principal tese é demonstrar o caráter popular da escola do Império e discutir que o seu fracasso na função de instruir e civilizar pobres, negros e mestiços pode estar exatamente relacionada à desqualificação da condição de educabilidade da clientela à qual se destinava a escola pública do século XIX. Destaca ainda a importância da temática para ampliação dos debates sobre a história da escola no Brasil.

Palavras-chave: história da educação; educação imperial; escola pública; classe social; etnia

Public schools for negroes and the poor in Brazil: an imperial invention This paper presents the final research data on the schooling of poor, negro and mixed-race children in Brazil, particularly in the province of Minas Gerais during the constitutionalist Monarchy (1824-1889). The main 